THE IMPACT OF CAPITAL-BASED REGULATION ON BANK RISK-TAKING: A DYNAMIC MODEL

\author{
Paul S. Calem \\ Division of Research and Statistics \\ Board of Governors of the Federal Reserve System \\ Rafael Rob \\ Department of Economics \\ University of Pennsylvania
}

March 1996

The views expressed in this paper are those of the authors and do not necessarily represent the views of the Board of Governors of the Federal Reserve System. We thank John Boyd, John Campbell, Mark Carey, David Jones, Myron Kwast, Mark Levonian, John Mingo, Eric Rosengren, and Bruce Smith for helpful suggestions. We thank David Jones for supplying us with a copy of his SAS program that simulates loan loss distributions. An early version of this paper was presented at the 1995 ASSA meetings. 


\section{Abstract}

In recent years, new and more stringent federal requlations governing bank capital have been adopted, including insurance premia linked to banks' capital-to-asset ratios and capital requirements linked to asset portfolio risk. In this paper, we model the dynamic portfolio choice problem facing banks, calibrate the model using empirical data from the banking industry for 19841993, and assess quantitatively the impact of the new regulations. The model suggests that two aspects of the new regulatory environment may have unintended effects: higher capital requirements may lead to increased portfolio risk, and capitalbased premia do not deter risk-taking by well-capitalized banks and tend to promote risk-taking among undercapitalized banks. On the other hand, risk-based capital standards may have favorable effects provided the requirements are stringent enough. 


\section{THE IMPACT OF CAPITAL-BASED REGULATION ON BANK RISK-TAKING: A DYNAMIC MODEL}

\section{Introduction}

In this article, we consider the impact of increasingly stringent and complex bank capital regulation on the moral hazard problem attributed to federal deposit insurance. In recent years, in the wake of the savings and loan crisis in the U.S., more stringent and complex capital regulation has been brought to bear upon federally-insured depository institutions. In 1988, the federal regulatory agencies adopted "risk-based" capital standards governing the ratio of capital to "risk-weighted" assets. These rules replaced simpler requirements pertaining to the ratio of capital to total assets and, in general, were more stringent than the old standards, particularly for larger banks (Avery and Berger 1991).1 In 1991, the Federal Deposit Insurance Corporation Improvement Act (FDICIA) was legislated. One important aspect of the new law was its requirement that the FDIC implement "riskrelated" pricing of deposit insurance. The FDIC responded by basing insurance premia on capital ratios and supervisory risk ratings, whereby banks with lower capital ratios and those assessed by examiners to be more risky pay higher premia. In addition, the so-called prompt corrective action provisions of FDICIA established five capital "zones" ranging from "critically

\footnotetext{
${ }^{1}$ Bank capital shields the deposit insurance fund from liability by absorbing bank losses and preventing bank insolvency. For this reason, capital regulation has long been a mainstay of banking supervision. Formal capital guidelines, including minimum required ratios of capital to total assets, were instituted by the federal regulatory agencies in 1981. Prior to that, federal regulators had supervised bank capital on a case-by-case basis. See wall (1989) for further discussion.
} 
undercapitalized" to "well-capitalized," and required bank regulators to implement progressively tighter restrictions on bank activities as capital declines.

These regulatory initiatives were aimed at discouraging bank risk-taking, preventing bank failures, and ensuring continued solvency of the deposit insurance fund. In large part, this expansion of capital-based regulation was an effort to address a moral hazard problem in banking, widely believed to derive from the federal deposit guarantee. Moral hazard is seen as arising because the government guarantee allows banks to make riskier loans without having to pay higher interest rates on deposits. As a result, banks may be prone to take on excessive risk. ${ }^{2}$ Indeed, there is mounting evidence that moral hazard has been a problem under the current deposit insurance contract; see Berlin, Saunders, and Udell (1991) and references therein.

In this paper, we attempt a dynamic modeling of the moral hazard problem and how it might be affected by various regulatory instruments. The model considers banks which operate in a multiperiod setting with the objective of maximizing the discounted value of their profits. In each period, and based on its capital position, a bank makes a portfolio choice; i.e., it decides how to allocate its assets between risky and safe investments. Then--as a result of the bank's portfolio choice, its pre-existing capital

\footnotetext{
${ }^{2}$ To policymakers and regulators, a potential social cost of bank risk-taking is the possibility that a major bank failure or series of failures could impose external costs on financial markets. See Bhattacharya and Thakor (1993) and Berger et. al (1994) for further discussion.
} 
position, and the realization of returns on its loans (which is a random variable)--the bank's capital position for the next period is determined (and the bank faces again the same portfolio choice problem, except that its capital position may now be different.) The goal of the model is to show how banks' banks portfolio choices adjust as their capital positions fluctuate over time. Relatedly (and equivalently), the model shows how portfolio choices differ among a cross-section of banks distinguished by their current capital positions. ${ }^{3}$

One can reasonably argue that the FDIC's risk-based premium assessments are based primarily on ex-post measures of risk, so that banks undertaking increased risk are assessed higher premia only in the event that their risk-taking results in losses. To investigate the incentive effects of the FDIC's pricing scheme, we incorporate capital-based premia into our model. The model also provides a natural framework for analyzing the impact of risk-based capital regulation, whereby a bank's capital requirement depends on its portfolio choice. These features are easily embedded into the model, since the opportunities a bank faces are allowed to depend on its capital position and on the portfolio choices it makes. Furthermore, since a bank's capital position varies over time and since capital positions vary across different banks (within the same time period), we are able to predict how different banks would

\footnotetext{
${ }^{3}$ One aspect of such a setting is that the bank will want to remain solvent and generate future profits, and this will partially offset the moralhazard problem that the bank is subject to (wanting to exploit a deposit insurance subsidy.) Keeley (1990) presents empirical findings consistent with the view that the incentive to protect future profits is a moderating influence on bank risk-taking.
} 
respond to the imposition of regulatory instruments.

After constructing a theoretical model embodying these features, we calibrate the model using a set of parameter values which come from empirical data on the banking sector during the period 1984-1993. We then numerically solve the model, and apply it to analyze the impact on bank risk-taking of increased capital standards, capital-based premia differentials, and risk-based capital requirements. The model yields a variety of interesting implications in regard to the efficacy of capital-based regulation.

For instance, we find that a premium surcharge imposed on undercapitalized banks worsens the moral hazard problem among these banks, boosting their incentive to take on risk. The underlying intuition is that the premium surcharge cuts into bank earnings, hampering the effort to recapitalize. Thus, the premium surcharge undercuts the ability of an undercapitalized bank to regain a favorable capital position without undertaking substantial risk. Surprisingly, however, we find that ex-post pricing of risk as represented by the premium surcharge has no appreciable impact on the behavior of a well-capitalized bank.

In the case of a flat (not risk-based) capital requirement, if the capital requirement is raised, then an ex-ante well capitalized bank will take on additional portfolio risk as it adds capital in accordance with the new standard. ${ }^{4}$ In most cases, however, an

${ }^{4}$ of course, the added capital will mitigate the impact of the increased portfolio risk. Nevertheless, the effect of regulatory capital requirements on bank portfolio risk is an important question, because, as emphasized by Berger et al. (1995), "binding regulatory capital requirements...involve a long-run social tradeoff between the benefits of reducing the risk of negative 
increase in the capital standard is found to have little impact on risk-taking behavior among undercapitalized banks. In one exceptional case, involving a very risky asset having an expected return lower than the return on the safe asset, we find that an increased capital standard results in expanded risk-taking among significantly undercapitalized banks.

We find that an increased risk-based capital standard is analogous to a higher flat standard, if the risk-based rule is not too stringent. That is, an ex-ante well capitalized bank will respond to the increased standard by adding capital and taking on more portfolio risk. If the risk-based rule is sufficiently stringent, however, then raising the standard will have a moderating impact on bank risk-taking. The latter result suggests that risk-based capital requirements are potentially an effective way to curtail moral hazard.

Our study differs substantially from previous studies of the relationship between capital regulation and bank risk-taking Previous contributions focused entirely on the impact of a flat capital standard. ${ }^{5}$ Further, the focus of these earlier studies was on a representative bank in a static framework with capital set ex-

externalities from bank failures and the costs of reducing bank intermediation." To the extent that capital requirements provide incentives for increased risktaking, the tradeoff becomes more severe, since "higher capital will be needed to achieve a given level of safety, thus reducing intermediation."

${ }^{5}$ Kahane (1977), Koehn and Santomero (1980), Kim and Santomero (1988), Keeton (1988), and Gennotte and Pyle (1991), demonstrate that banks may choose higher-risk portfolios in response to a higher capital requirement. In the models of Kareken and Wallace (1978), Furlong and Keeley (1989) and Furlong and Keeley (1990), the deposit insurance subsidy induces a representative bank to hold the riskiest assets available without regard to the minimum capital standard. 
ante at the level required by regulation. Such a framework precludes consideration of intertemporal consequences of risktaking, precludes cross-sectional predictions regarding the behavior of both well-capitalized and undercapitalized banks, and cannot be applied to analyze the impact of risk-based capital regulation.

The paper is organized as follows. The model is constructed in section 2. Section 3 deals with calibration of the model. In section 4, we solve the model assuming a flat (not risk-based) capital standard and flat deposit insurance pricing, and investigate the impact of varying the calibration holding regulatory parameters constant. In section 5, we analyze the effect of a higher minimum capital standard and the impact of insurance premia penalties. Risk-based capital requirements are considered in section 6 . Section 7 concludes.

\section{The Model}

We consider the dynamics of bank portfolio choice in a multiperiod (infinite horizon) model. Bank size (total assets) is exogenously set at 1 . Assets are funded by deposits $D$ and capital C; thus, $C+D=1$. At the beginning of each period, the bank chooses a portfolio allocation consisting of $S$ units of a safe asset and $R$ units of a risky asset; $R+S=1$. The cost of deposits is given by the function $\rho(\mathrm{C})$, where:

(1) $\rho(C) \equiv \rho_{0}+\pi_{1}$ if $C=C^{*} ; \quad \rho(C) \equiv \rho_{0}+\pi_{2}$ if $C<C^{*} ; \pi_{1} \leq \pi_{2}$. $\mathrm{C}=\mathrm{C}^{\star}$ represents a minimum capital requirement imposed by 
regulation. The case $\pi_{1}=\pi_{2}$ corresponds to fixed rate deposit insurance premia; the case $\pi_{1}<\pi_{2}$ corresponds to capital-based deposit insurance premia (or other "penalties" for falling below the regulatory capital requirement.) In addition to deposit expenses, the bank incurs a per-period fixed operating cost $F$.

The safe asset earns a certain, end-of-period gross return $\mathrm{x}$ $>1$ per unit of investment. Ex-ante, the risky asset promises the gross return $\mathrm{y}_{0}>\mathrm{x}$ per unit invested, but ex-post, a fraction u of the investment in the risky asset yields a gross return of 0 ; i.e., this fraction is lost. The remaining fraction, 1 - u, yields the promised return $y_{0}$. Thus, the realized gross return per unit invested in the risky asset is $y(u) \equiv y_{0}(1-u)$. The fractional loss $u$ is a random variable taking on values between 0 and 1 , drawn from a distribution with density function $g(u)$ and cumulative distribution function $G(u)$. Empirical estimates of the various cost parameters and asset return characteristics (x, F, g, etc.) are provided in the next section.

In any period, the bank's owners (stockholders) earn the residual return on the bank's investments after the bank has paid its depositors, met its fixed expenses, and met the minimum capital requirement. Formally, let $z(C, R, u)$ denote the return net of payments to depositors and fixed expenditures that is implied by a beginning of period capital level C, a portfolio choice R, and a loss realization u:

$$
z(C, R, u) \equiv x(1-R)+y(u) R-\rho(C)(1-C)-F .
$$

If $z(C, R, u) \geq C^{*}$, stockholders earn $z(C, R, u)-C^{*}$. If $0<z(C, R, u)$ 
$<C^{*}$, the return is insufficient to meet the regulatory capital requirement, stockholders earn zero, and the entire net return that period goes toward next period's capital. ${ }^{6}$ If $z(C, R, u) \leq 0$, the bank ceases to exist and the FDIC pays off depositors after claiming the return on the bank's asset portfolio.

It follows that the set of fractional losses consistent with continued bank solvency is bounded above by $u_{A}$, where $u_{A}$ satisfies $z(C, R, u)=0$. Similarly, the set of fractional losses consistent with positive stockholder earnings is bounded above by $u_{B}$, where $u_{B}$ satisfies $z(C, R, u)=C^{\star}$. Thus:

$$
\mathrm{u}_{\mathrm{A}}=\left[\mathrm{x}(1-\mathrm{R})+\mathrm{y}_{0} \mathrm{R}-\rho(\mathrm{C})(1-\mathrm{C})-\mathrm{F}\right] / \mathrm{y}_{0} \mathrm{R} ;
$$$$
u_{B}=u_{A}-\left(C * / y_{0} R\right) \text {. }
$$

Note that $u_{A}$ and $u_{B}$ are functions of $C$ and $R$.

In this framework, the bank's optimal investment in the risky asset will depend only on $\mathrm{C}$, the state variable. We denote this optimal investment function $\mathrm{R}(\mathrm{C})$. It is determined along with the value function $\mathrm{V}(\mathrm{C})$ as the solution to the dynamic programming problem:

$$
V(C) \equiv \max _{R}\left\{\int_{0}^{u_{B}}\left[z(C, R, u)-C^{*}\right] g(u) d u+\delta V\left(C^{*}\right) \int_{0}^{u_{B}} g(u) d u\right.
$$

$$
\left.+\delta \int_{u_{B}}^{u_{A}^{A}}[V(z(C, R, u)) g(u) d u]\right\},
$$

where $\delta$ denotes the rate at which stockholders discount future earnings. The maximand in (5) can be understood as follows. The

${ }^{6}$ This assumption is consistent with regulatory requirements mandated by FDICIA, whereby undercapitalized banks are prohibited from paying dividends or paying management fees to a parent holding company. 
first term represents expected current-period earnings, since stockholders earn $z(C, R, u)-C^{*}$ in the event of a favorable realization $u \leq u_{B}$ and they earn zero otherwise. The second term represents the continuation value when the bank meets the capital requirement at the end of the current period, weighted by the probability that this will be the case, and the third term is the expected continuation value when the bank cannot meet the capital requirement (but is still solvent).

Let $E\left[u \mid u \leq u_{B}\right]=\int_{0}^{u_{B}}(u) d u$. Since $z(C, R, u)-C^{\star}=y_{0}\left(u_{B}-u\right)$, we can rewrite (5) in the more amenable form:

$$
V(C)=\max _{R}\left\{u_{B} Y_{0} R G\left(u_{B}\right)-R y_{0} E\left[u \mid u \leq u_{B}\right]+\delta V\left(C^{*}\right) G\left(u_{B}\right)\right.
$$

$$
+\delta \int\left[\begin{array}{l}
u_{A} \\
u_{B}
\end{array}\right.
$$

Since (6) is not analytically solvable, we generate a numerical solution. Towards that, let us discretize the problem as follows. Define $\mathrm{N}=\mathrm{C} * / 0.002$ points $\mathrm{C}_{i}$ along the range of feasible capital positions $\left(0, C^{\star}\right]$ :

$$
\mathrm{C}_{1}=0.002 ; \quad \mathrm{C}_{\mathrm{i}+1}=\mathrm{C}_{\mathrm{i}}+0.002, \mathrm{I}=1, \ldots \mathrm{N} ; \mathrm{N}=\mathrm{C}^{\star} / 0.002
$$

and 20 points $R_{j}$ in $[0,1]$ :

$$
R_{1}=.05 ; \quad R_{i+1}=R_{i}+0.05, I=1, \ldots, 20 \text {. }
$$

In addition, to each $C_{i}, R_{j}$, attribute $N$ points $u_{k}$ in $\left[u_{B}, u_{A}\right]$ :

$$
u_{k}=u_{A}-(0.002) \mathrm{k} /\left(1+y_{0}\right) R_{j}, k=1, \ldots, N \text {. }
$$

Thus, $u_{k}$ represents the fractional loss that would leave the bank with $(0.002) \mathrm{k}$ units of capital at the end of the period, given that the bank began the period with $C_{i}$ units of capital and the portfolio position $R_{j}$. Note that $C_{N}=C^{*}, u_{0}=u_{A}$, and $u_{N}=u_{B}$. 
The numerical solution to (6) will then be a set of portfolio positions $R^{\star}\left(C_{i}\right) \equiv R_{i}^{*}$ and a set of discounted present values $\mathrm{V}^{*}\left(\mathrm{C}_{\mathrm{i}}\right) \equiv \mathrm{V}_{\mathrm{i}}{ }^{*}, \mathrm{I}=1, \ldots, \mathrm{N}$, such that $\mathrm{R}_{\mathrm{i}}^{*}$ solves:

$$
\begin{aligned}
\max _{R_{j}}\left\{u_{B} Y_{0} R_{j} G\left(u_{B}\right)-y_{0} R_{j} E\left[u \mid u \leq u_{B}\right]+\delta V_{N}^{*} G\left(u_{B}\right)\right. \\
\left.\left.+\sum_{k=1}^{N-1}\left[\left(V_{k}^{*}+V_{k+1}^{\star}\right) / 2\right)\right]\left[G\left(u_{k+1}\right)-G\left(u_{k}\right)\right]\right\}
\end{aligned}
$$

and such that $V_{i}^{*}$ satisfies (to close approximation):

$$
\mathrm{V}_{\mathrm{i}}^{*}=\mathrm{u}_{\mathrm{B}} \mathrm{Y}_{0} \mathrm{R}_{\mathrm{i}}^{*} \mathrm{G}\left(\mathrm{u}_{\mathrm{B}}\right)-\mathrm{y}_{0} \mathrm{R}_{\mathrm{i}}^{*} \mathrm{E}\left[\mathrm{u} \mid \mathrm{u} \leq_{\mathrm{B}}\right]+\delta \mathrm{V}_{\mathrm{N}}^{*} \mathrm{G}\left(\mathrm{u}_{\mathrm{B}}\right)
$$

$$
+\sum_{k=1}^{N-1} \delta\left[\left(V_{k}^{*}+V_{k+1}^{*}\right) / 2\right]\left[G\left(u_{k+1}\right)-G\left(u_{k}\right)\right]
$$

for each I. Note that $u_{{ }_{B}} u_{k^{\prime}}$ and $u_{k+1}$ in (10) are evaluated at $C_{i}$ and $R_{j}$, while $u_{B}{ } u_{k}$, and $u_{k+1}$ in (11) are evaluated at $C_{I}$ and $R^{*}\left(C_{i}\right)$. Condition (10) states that for each $I_{,} R^{*}{ }_{I}$ is the portfolio allocation that maximizes $\mathrm{V}\left(\mathrm{C}_{\mathrm{i}}\right)$, the expected value of current and discounted future earnings. The corresponding maximum value of $\mathrm{V}\left(\mathrm{C}_{\mathrm{i}}\right)$ is $\mathrm{V}_{\mathrm{i}}^{\star}$ as defined by (11).

\section{Calibration of the Model}

Computation of a numerical solution to (10) and (11) is straightforward once a probability distribution $G(u)$ is specified and parameter values are assigned. ${ }^{7}$ Parameters to be calibrated include: the deposit interest rate $\rho_{0} ;$ the return $\mathrm{x}$ on the safe asset; the discount factor $\delta$; operating costs $F$; the ex ante promised return on the risky asset $\mathrm{y}_{0} ;$ and the parameters of the

\footnotetext{
${ }^{7}$ The Fortran programs used to compute the solutions discussed below are obtainable from the authors upon request.
} 
specified probability distribution G(u) .

Deposit and operating costs and the return on the safe asset. We assign values to $\rho_{0}, \mathrm{x}, \delta$, and $F$ that are consistent with observed data from the banking industry, and hold these constant for the duration of our analysis. The results are robust to varying these parameters within a reasonable range. ${ }^{8}$

We equate $\rho_{0}$ with the interest expense per dollar of deposits of an "average" bank, determined as follows. We draw on a panel data set consisting of end-of-year, Call Report data from the years 1984 through 1993. Every U.S. commercial bank having at least \$300 million in assets and at least a 6 percent ratio of equity capital to assets as of year-end 1984 is included in the panel. 9 First, we compute the sample means, by year, of interest expense per dollarof-deposits. ${ }^{10}$ Then, we compute the mean of these means across years, which is used to calibrate $\rho_{0}$. We employ this two-step procedure in order to avoid placing disproportionate weight on earlier years, since the number of banks in the panel was declining over time. The empirical estimate we obtain in this way is $\rho_{0}=1.048$. Similarly, we equate the operating cost parameter $\mathrm{F}$ with an "average" bank's operating cost per unit-of-assets to obtain

\footnotetext{
${ }^{8}$ The results are robust to varying these parameters so long as the net return on the safe asset (return net of deposit and operating costs) remains sufficiently larger than zero. The solutions converge to maximal risk-taking at all capital levels when the net return on the safe asset approaches zero.

${ }^{9}$ Attention is confined to this period because modifications to the Call Reports that were instituted in 1985 introduced certain inconsistencies with earlier years' data. Extreme values were deleted from this panel data set.

${ }^{10}$ Interest expense per dollar of deposits for year [t-1,t] is total deposit interest expenses incurred during the period [t-1,t]; i.e., during the year prior to date $t$, divided by average total deposits for the reporting dates $t-1$ and $t$.
} 
$\mathrm{F}=0.02 .{ }^{11}$

The return on the model's safe asset, net of per-unit operating costs, is set equal to the average interest rate on 6month treasury bills over 1985-1993. Since the 6-month t-bill rate averaged 1.06 over 1985 through 1993 , we set $x=1.06+0.020=1.08$. Finally, we set $\delta=1 / 1.06=0.94$. Table 1 summarizes these calibrations.

Calibration of the loss distribution. To calibrate the probability distribution of losses on the risky asset, we proceed as follows. We equate investment in the risky asset with investment in a credit portfolio, and then apply a method of simulating portfolio loss distributions developed by McAllister and Mingo (1995) and Jones (1995). This method involves simulating a sample of 10,000 random rates of return on a hypothetical loan portfolio. An individual borrower's default probability (denoted d) must be specified, along with a "market risk" parameter $\left(\mathrm{b}^{2}\right)$ that determines the correlation between the returns on any two loans. This parameter affects the degree of diversification within the loan pool. ${ }^{12}$ The magnitude of the loss incurred in the event of default is another key parameter. For further details, see

\footnotetext{
${ }^{11}$ We first compute the mean, by year, of annual noninterest expenses net of noninterest income divided by total assets (i.e., net noninterest expenses during $[t-1, t]$ divided by average total assets for dates $t-1$ and $t$.) we then compute the mean of these means across years.

${ }^{12}$ Thus, a low correlation implies that the performances of individual loans are nearly independent, in which case the pool default rate will be close to the individual default probability d. A higher correlation implies that defaults, when they occur, will tend to occur together.
} 
McAllister and Mingo (1995) and Jones (1995). ${ }^{13}$

The loans comprising the model's risky asset are presumed to be riskier than the "typical" bank loan. Such a characterization seems appropriate, as it seems reasonable to draw a distinction between moral hazard and "normal" bank lending activities. Our analysis below experiments with alternative parameter specifications consistent with such a characterization.

Jones (1995) suggests that the average quality of commercial loans in the portfolios of money center and super-regional banks lies somewhere in the range corresponding to corporate bonds rated B through Ba. According to Moody's 1994, loss rates within one year of issue on B-rated bonds historically have averaged around 8 percent. We adopt this 8 percent figure as a lower bound on the default probability (d) for the loans comprising our model's risky asset.

Following McAllister and Mingo (1995), with respect to the market risk parameter $\left(\mathrm{b}^{2}\right)$, our analysis focuses on calibrations ranging between 20 and 33 percent. These authors indicate that available data from the banking industry are consistent with correlations in this range.

The severity of loss given default is assumed to be "businesscycle dependent". Specifically, the loss distributions utilized

\footnotetext{
${ }^{13}$ We adopted the particular approach employed by Jones (1995), whereby a loan is invested in a project that yields a random return. A default occurs if the return on the project is insufficient to cover the loan repayment; the loss given default is assumed to be a fixed proportion of the loan amount. The contractual interest rate on a loan has a slight impact on the shape of the loss distribution generated by this model, since it affects whether a random return produces a default.
} 
below assume a loss given default of 30 percent given a favorable outcome of the market risk factor, and a higher loss otherwise, for an expected loss given default ranging from 40 to 42 percent. ${ }^{14}$ This specification of loss given default seems reasonable based on available data. For instance, drawing on the panel data set introduced previously, we compute an average loan default rate and an average net loss rate of 0.0228 and 0.0087 , respectively. ${ }^{15}$ The latter divided by the former, which might be viewed as a typical loss given default, equals 0.38. In addition, it is interesting to note that an independent report by the Society of Actuaries (1993) finds a 44 percent loss severity (loss per unit of credit exposure) on defaulted private placement bonds, on average, for issuers rated $\mathrm{BB}$ or lower. Further, the mean across banks of net losses per dollar loaned exhibits somewhat greater year-to-year variation than the annual mean default rate. ${ }^{16}$ This suggests that the severity of losses given default may be affected by the business cycle.

Distributions generated via this approach exhibit a

${ }^{14}$ The systemic risk factor $\mathrm{s}$ is standard normally distributed. The loss given default is 30 percent of the dollar amount of exposed principal when $\mathbf{s} \geq$ 0 . For $\mathrm{s}<0$, losses are assumed to increase with - s, up to a maximum loss of .80 for $s<-2.0$.

${ }^{15} \mathrm{~A}$ bank's default rate for year $[t-1, t]$ is defined to be the ratio of problem loans (loans 90 days or more past due and non-accruing loans) to total loans, calculated at date $t$. We compute the mean default rate across banks for each year, and then compute the mean of these means across years, which we take to be the average loan default rate for the panel. A bank's loss rate for year $[t-1, t]$ is defined to be the ratio of net charge-offs (charge-offs minus recoveries) during year $[t-1, t]$ divided by average total loans for the reporting dates t-1 and $t$. We compute the mean loss rate across banks for each year, and then compute the mean of these means across years, which we take to be the average loss rate for the panel.

${ }^{16}$ The standard deviation over time of the annual mean loss rate is 0.0016 , which equals 19 percent of the mean loss rate; the standard deviation over time of the annual mean default rate is 0.0032 , equal to 14 percent of the mean default rate. 
characteristic shape. Percentiles of one such loss distribution are shown in column $A$ of table 2. This distribution assumes an 8 percent individual default probability (d), a 33 percent correlation between loan rates of return $\left(\mathrm{b}^{2}\right)$, and a loan interest rate $\mathrm{y}_{0}=1.14$. Column $\mathrm{B}$ presents percentiles of the distribution obtained when the correlation parameter is reduced to 25 percent. These distributions rise very slowly through the median and then become progressively steeper, rising sharply through the upper percentiles.

Piecewise linear approximation to the distribution. For the purpose of obtaining numerical solutions to our model, we approximate each generated loan loss distribution by means of a piecewise linear distribution with support $\left[u^{0}, u^{8}\right]$, where $u^{0}=0$ :

$$
\begin{aligned}
& F(u)=\left(u-u^{0}\right) /\left(u^{1}-u^{0}\right) \text { if } u^{0} \leq u \leq u^{1} ; \\
& F(u)=F\left(u^{i}\right)+\left(u-u^{i}\right) /\left(u^{i+1}-u^{i}\right) \text { if } u^{i} \leq u \leq u^{i+1} ; I=0, \ldots, 8 .
\end{aligned}
$$

In (12), $u^{0}, u^{1}, \ldots u^{8}$ denote, respectively, the 0th, 1st, 5th, 25th, 50th, 75th, 95th, 99th, and 100th percentile of the distribution. To implement each generated loan loss distribution, we approximate it via appropriate calibration of the parameters $u_{1}$, $u_{8}$ in (12). ${ }^{17}$

Calibration of the promised return on the risky asset. It remains to calibrate $y_{0}$, the contractual interest rate on loans comprising the risky asset. Given a specification of the loan loss distribution, it might seem reasonable to calibrate $y_{0}$ by observing market spreads on loans of comparable riskiness. Data relating

\footnotetext{
${ }^{17}$ Details regarding the procedure used to calibrate (12) are available from the authors upon request.
} 
bank loan spreads to measures of risk are unavailable, however. Instead, we experiment with various calibrations of $y_{0}$ in association with each specified loan loss distribution.

Mostly, we assume that the expected return on the risky asset would exceed the return on the safe asset by a reasonable amount. ${ }^{18}$ Consequently, the calibrations we utilize below generally involve spreads of 800 basis points or more between $y_{0}$ and the average 6month t-bill rate $(1.06)$. Spreads of this size are well within the realm of plausibility. For instance, U.S. Small Business Administration (1993) reports that spreads of 800 to 1200 basis points are not uncommon for short-term, fixed-rate small business loans. ${ }^{19}$

\section{Solution under Alternative Calibrations of the Risky Asset}

In this section, we demonstrate that the solution to the model tends to be roughly U-shaped, with notable persistence across alternative calibrations of the probability distribution of returns on the risky asset. Throughout this section, we assume a flat deposit insurance premium $\left(\pi_{1}=\pi_{2}\right)$ held constant at $\pi_{1}=0.0025$, and we hold the minimum capital requirement constant at $C^{\star}=0.06$.

\footnotetext{
${ }^{18}$ Normally, one would expect a risky asset to provide a higher expected return than a safe asset. In cases corresponding to more extreme moral hazard, however, the risky asset might have an expected return below the return on the safe asset. An example of this is considered below.

${ }^{19}$ Among B-rated private-placement bonds (which tend to exhibit narrower spreads than B-rated publicly-traded bonds), spreads of 800 basis points or more over comparable maturity t-bonds are uncommon, although not so uncommon as to be considered outliers (Carey and Luckner 1995). Due to the more intensive information production and higher monitoring costs associated with bank loans, however (Carey et. al 1995), one cannot assume that spreads on risky bank loans would be confined to a similar range.
} 
Table $3 a$ presents the solution to the model under three alternative calibrations of the distribution of returns on the risky asset. Each of these assume an individual default probability $d=0.08$ and an ex-ante promised return $y_{0}=1.145$. The three specifications differ with respect to the assumed correlation $\mathrm{b}^{2}$ between asset returns, which ranges from 0.25 to 0.33 .

Table $3 b$ presents the solution to the model under some additional calibrations of the distribution of returns on the risky asset. For these calibrations, the assumed individual default probability is not held constant but ranges from 0.09 to 0.12 , and the promised return $y_{0}$ is assumed to increase with the default risk.

The parameters underlying the distribution of returns $\left(\mathrm{d}, \mathrm{b}^{2}\right.$, and $\mathrm{y}_{0}$ ) are listed at the top of each column, and the solution to the model under that calibration is indicated below. Also noted at the top of the column is the corresponding expected return (denoted Rt) on the risky asset.

The solutions depicted in tables $3 a$ and $3 b$ are roughly Ushaped, with the amount of risk depending on the bank's current capital position. In general, a severely undercapitalized bank takes maximal risk in an effort to improve its capital position. This implication of the model provides a formal rationale for the prompt corrective action provisions of FDICIA, which require progressively more strict regulatory intervention as a bank's 
capital declines. ${ }^{20}$ A more modestly undercapitalized bank takes much less risk, trying to ensure it doesn't go under. Finally, as capital rises and the bank is more remote from bankruptcy, the bank takes on more risk, if the risky asset is associated with a higher expected return than the safe asset. This characteristic shape can be understood as follows.

In the case a severely undercapitalized bank, maximal risktaking arises because the proportion invested in the risky asset, whether large or small, does not significantly affect the probability of insolvency, since only a small erosion of the bank's capital suffices for insolvency. Rather, incremental risk primarily affects the loss incurred (by the deposit insurance fund) in the event of insolvency. On the other hand, unless it undertakes substantial risk, a severely under-capitalized bank stands little chance of regaining a favorable capital position.

A less severely undercapitalized bank takes on comparatively little risk; its predominant concern is to avoid insolvency or further erosions of capital. For this bank, incremental risktaking has a more significant impact on the probability of (eventual) insolvency, and this bank stands a better chance of

\footnotetext{
${ }^{20}$ Banks in capital zone 1 (well capitalized) face no mandatory restrictions on activities. Those in zone 2 (adequately capitalized) are subject to increased regulatory scrutiny, including more frequent supervisory exams and prior FDIC approval to accept brokered deposits. Banks in capital zone 3 (undercapitalized) face several mandatory restrictions; for instance, these banks are prohibited from accepting brokered deposits and from paying dividends or management fees, and they are subject to restrictions on asset growth. Those in zone 4 (significantly undercapitalized) are subject to the same restrictions as those in zone 3 plus several additional ones, including restrictions on interaffiliate transactions, on deposit interest rates, and on officer compensation. Banks in capital zone 5 (critically undercapitalized) are subject to still more restrictions, and generally must be placed in receivership or conservatorship within 90 days after being classified as critically undercapitalized.
} 
regaining a favorable capital position without undertakingsubstantial risk.

A well-capitalized bank can afford to take more risk because it is more remote from bankruptcy. This bank would stand a good chance of recovery should it incur an erosion of capital due to loan losses.

The effects of parameter changes. The solutions are not highly sensitive to changes in the promised return on the risky asset $\left(\mathrm{y}_{0}\right)$, holding other parameters constant. Consider, for example, the solution depicted in table 3a, column (I). Small increases (or decreases) in $y_{0}$ above (below) 1.145 yield a modest expansion (contraction) of the range of maximal risk-taking among undercapitalized banks. Within a 50 basis point range (1.1425 $\leq \mathrm{y}_{0}$ $\leq 1.1475)$, changes in $y_{0}$ have no impact on $R^{*}\left(C^{*}\right)$; i.e., on the solution as it pertains to a well-capitalized bank. The other solutions depicted in tables $3 a$ and $3 b$ are no less robust; for instance, within a 60 basis point range (1.051 $\left.\leq y_{0} \leq 1.057\right)$, changes in $y_{0}$ have little impact on the solution depicted in table 3b, column (I).

Ultimately, as $y_{0}$ declines, the solution collapses to minimal risk-taking at all capital levels. Likewise, a sufficiently large increase in $y_{0}$ yields maximal risk-taking at all capital levels. Calibrations of $y_{0}$ that yield minimal (or maximal) risk-taking at all capital levels are of limited interest. Differing regulatory policies or parameters generally have no impact on the solutions in these cases. Moreover, minimal (maximal) risk-taking by all banks 
would seem inconsistent with an equilibrium in the asset market (although that is outside the scope of our model). With all banks seeking to invest solely in the safe (risky) asset, one would expect the contractual interest rate $y_{0}$ to be driven up (down) by competitive pressures.

A reduction in the correlation of rates of return on risky loans $\left(\mathrm{b}^{2}\right)$ yields a contraction of the range of maximal risk-taking among undercapitalized banks. This is clearly illustrated by the solutions depicted in table $3 a$. With $y_{0}=1.145, d=0.08$, and $b^{2}=0.33$, maximal risk-taking arises at all capital levels less than or equal to 0.008. Holding $y_{0}$ and $d$ constant, the range of maximal risktaking contracts as $\mathrm{b}^{2}$ is reduced to 0.30 , and it disappears entirely with $\mathrm{b}^{2}=0.25$. Moreover, a decrease in the correlation parameter $\mathrm{b}^{2}$ is associated with increased risk-taking by wellcapitalized banks .

These effects of changing the correlation parameter $b^{2}$ can be understood as follows. With an increase in $\mathrm{b}^{2}$, the largest potential losses occur with increased probability, but the likelihood that losses will be only small or negligible also increases, and the median loss declines. That is, the loss distribution function becomes more concave; compare, for example, column A with column B in table 2. The first factor (increased probability with respect to the largest potential losses) tends to deter risk-taking by well-capitalized banks. The second factor tends to encourage risk-taking by undercapitalized banks.

The range of maximal risk-taking also widens with concomitant 
increases in $d$ and $y_{0}$. Consider, for instance, column (ii) of table $3 b$ in comparison to column (iii) of table 3a. The following intuition underlies this effect. The increase in the ex-ante interest rate provides an incentive to take on more risk, while the increased probability of default provides an opposing incentive. For a bank that is significantly undercapitalized, the former dominates, because the expected losses associated with the increased probability of default are borne primarily by the deposit insurer rather than by the bank.

Comparing column (I) of table $3 \mathrm{~b}$ to column (ii) of table $3 a$, we see again that increases in $y_{0}$ and $d$ lead to an expansion of risk-taking among undercapitalized banks. Note, in this case, that the increases in $y_{0}$ (from 1.145 to 1.155) and $d$ (from 0.08 to 0.09 ) are assumed to be accompanied by a reduction in $\mathrm{b}_{2}$ (from 0.30 to 0.28). Without this assumption, the increases in $y_{0}$ and $d$ would make risk-taking so attractive as to yield maximal risk-taking at all capital levels. Further increases in $y_{0}$ (to 1.168) and d (to 0.11), when accompanied by a further reduction in $\mathrm{b}^{2}$ (to 0.20 ), yields the solution depicted in column (iii) of table 3b.

When the expected return on the risky asset is below the riskfree return, well capitalized banks take on minimum risk; i.e., $R^{*}\left(C^{*}\right)=0.05$. Maximal risk-taking may persist, however, among severely under-capitalized banks. Consider, for instance, the case depicted in column (iv) of table 3b. In this case, the probability of default on an individual loan in the risky asset portfolio is 0.15, and the correlation of loan rates of return is 0.33 , implying 
very high risk. Moreover, the expected return on the risky asset (given the specified $\mathrm{y}_{0}$ ) is lower than that provided by the safe asset. The range of maximal risk-taking among undercapitalized banks is quite extensive, but at capital levels above this range, minimal risk-taking is the outcome.

\section{Increased Capital Standards and Capital-Based Premia}

To analyze the impact of an increase in the capital requirement, we now solve the model with $C^{*}=0.07$ in place of $C^{\star}=0.06$. Table 4 depicts the solutions thus obtained, for several of the calibrations introduced in the previous section.

Comparing the solutions in table 4 to their counterparts in tables $3 a$ and $3 b$, it is clear that when the capital requirement is raised and an ex-ante well capitalized bank increases its capital to meet the new standard, the bank generally takes on more portfolio risk. This is consistent with the overall U-shape of the solution, whereby beyond the lowest capital levels, risk-taking tends to increase with capitalization.

Note, however, that the increased regulatory standard appears to have a moderating effect on risk-taking at some intermediate capital levels. For example, comparing column (ii) of table 4 to column (iii) of table 3b, we observe an ex-post decline in risktaking (from $R^{*}=.50$ to $R^{*}=.10$ ) at capital levels $0.056<C \leq 0.060$.

In general, an increase in the capital standard appears to have little impact on the range of maximal risk-taking among severely undercapitalized banks. An important exception, however, 
is the case of extreme moral hazard depicted in table 3b, column (iv). Recall that in this case, significantly undercapitalized banks exploit an opportunity to invest in an extremely risky asset (d=0.15), gambling on a high return. Comparing column (iii) of table 4 to column (iv) of table 3b, we find that raising the regulatory capital standard has a deleterious impact in this case; i.e., the range of maximal risk-taking among undercapitalized banks expands substantially. Ex-post, banks engage in maximal risk taking at all capital levels below 4.4 percent. This suggests that an increase in the minimum capital standard may generate a need for increased vigilance with respect to supervision of undercapitalized banks.

Capital-based premia. As noted in the introduction, one important aspect of FDICIA was its requirement that the FDIC implement "risk-related" pricing of deposit insurance. The FDIC responded by basing insurance premia on bank capital ratios and on supervisory risk ratings that reflect examiner evaluations of bank earnings, asset quality, liquidity, and management. Banks with lower capital ratios and those assessed by examiners to be more risky pay higher premia. These risk-based premia, when first introduced, ranged from 23 to 31 basis points across risk categories. Recently, the FDIC amended its deposit insurance premium regulations to establish a new rate schedule. The new risk-based premia range from 4 to 31 basis points.

One can reasonably argue that premium assessments under this regulation are based primarily on ex-post indicators, whereby banks 
undertaking increased risk are assessed higher premia only in the event that their risk-taking results in losses. To investigate the incentive effects of such ex-post pricing of risk, we solve the model assuming a capital-based premium differential, with $\pi_{1}=$ 0.0025 and $\pi_{2}=0.0035$, holding $C^{*}$ constant at $0.06 .{ }^{21}$ Table 5 depicts the solutions thus obtained, for several of the calibrations examined previously.

Comparison of table 5 with tables $3 a$ and $3 b$ reveals that introduction of the deposit premium differential has a substantial impact in the case of significantly undercapitalized banks, in the direction of increased risk-taking. For example, comparing column (I) of table 5 to column (I) of table $3 a$, we observe that the introduction of the premium differential causes banks at capital levels greater than 0.008 and less than or equal to 0.030 to jump from minimal risk-taking $\left(R^{*}=0.05\right)$ to holding only risky assets $\left(R^{\star}=1.0\right)$. The underlying intuition is that the premium surcharge cuts into bank earnings, hampering the effort to recapitalize. Thus, the premium surcharge undercuts the ability of an undercapitalized bank to regain a favorable capital position without undertaking substantial risk.

This comparison also indicates that introduction of the premium differential has, at best, a slight impact on moderately undercapitalized banks, in the direction of reduced risk-taking. We observe no impact at all on the behavior a well-capitalized

\footnotetext{
${ }^{21}$ Alternative calibrations of the premium differential yield qualitatively simlar results.
} 
bank; i.e., increasing the premium differential does not appear to have any deterrent effect on risk-taking among well-capitalized banks. This result can be understood as follows. Risk-taking in the model is represented by increased investment in a risky asset. This asset is characterized by a loss distribution that is highly skewed and has a long tail (it is leptokurtic), so that losses only rarely occur but tend to be very large when they do occur. On the margin, increased investment in such a risky asset has only a slight impact on a bank's probability of becoming undercapitalized. Consider, for example, the solution depicted in column (I) of table 3a. In this case, a well-capitalized bank invests $R^{*}\left(C^{*}\right)=0.55$ in the risky asset and with probability $\mathrm{F}\left(\mathrm{u}_{\mathrm{B}}\right)=0.78792$, remains wellcapitalized into the subsequent period. If the bank were to reduce its investment in the risky asset to 0.50 , its probability of remaining well-capitalized would rise to 0.79157 , an increase of only 0.00365 .

Hence, in our model the premium penalty associated with becoming undercapitalized has no appreciable incentive effect on the behavior of well capitalized banks. An open question, which we leave to future research to investigate, is whether a similar result would be obtained if risk-taking were represented as the inclusion of progressively risky types of assets in a portfolio, rather than as incremental units of a given asset.

These results are robust to varying any of the calibrations 
within reasonable ranges. ${ }^{22}$ The results are also robust to assuming a higher minimum capital standard, or to modifying the size of the assumed premium differential. In sum, the primary effect of an insurance premium surcharge on undercapitalized banks is to substantially aggravate the moral hazard problem among undercapitalized banks, and this implication of the model is highly robust across alternative calibrations.

\section{The Impact of Risk-Based Capital Requirements}

As noted in the introduction, in 1988 the federal regulatory agencies adopted "risk-based" capital standards that were effectively more stringent than the prior standards, particularly for larger banks (Avery and Berger 1991). Under the prior standards, primary capital had to be at least 6 percent of total balance sheet assets or the bank would face supervisory action. ${ }^{23}$ Under the risk-based standards, differing weights are assigned to various categories of bank assets (e.g. home mortgage loans, treasury bills, commercial loans) prior to summing the assets, to reflect differences in credit risk. The regulations adopted in 1988 required that total capital be at least 8 percent of riskweighted assets (where loan loss reserves were no longer to be fully included as a component of measured capital). In addition,

\footnotetext{
${ }^{22}$ These would be ranges within which the solution under a flat capital requirement retains something of a "U-shape" (i.e., does not collapse to minimal risk-taking at all capital levels or to maximal risk-taking at all capital levels.)

${ }^{23}$ Primary capital was defined to include equity, loan loss reserves, preferred stock, and various kinds of debentures; see wall (1989) for details.
} 
these regulations set standards for tier-one capital (a more restrictive definition of capital) in relation to risk-weighted assets and for tier-one capital in relation to total assets. ${ }^{24,25}$ In this section, we examine the consequences for bank portfolio choice of risk-weighting of assets in computation of regulatory capital. Before we proceed, however, a word of caution is in order. While our model may provide some insight into the effects of a risk-based capital standard, the model is subject to an important limitation. In practice, very broad risk-categories of assets are defined for the purpose of calculating regulatory capital requirements. For instance, the highest-risk category would incorporate all of a bank's commercial and industrial ( $\mathrm{C}$ and I) lending. Thus, in practice, a bank might respond to a binding risk-based requirement primarily by reducing its investment in assets that, unlike the model's risky asset, may not be excessively risky. For instance, a bank might curtail moderately risky C and I lending. Consideration of this issue would require a model with

\footnotetext{
${ }^{24} \mathrm{In}$ addition, the 1988 requlation required banks to hold some capital against off-balance sheet activities. Banks were directed to comply with the new standards by 1992. See wall (1989) for details.

${ }^{25}$ As noted previously (see footnote 20), FDICIA introduced a distinction between well capitalized and adequately capitalized (as well as three distinct categories of undercapitalized), whereby the latter are subject to closer regulatory scrutiny. Thus, for instance, under current regulations, total capital has to be at least 8 percent of risk-weighted assets for a bank to be considered adquately capitalized, and at least 10 percent of risk-weighted assets for a bank to be considered well capitalized. In addition, there are tests for well capitalized vs. adquately capitalized that are based on tier-one capital in relation to risk-weighted assets and tier-one capital in relation to total assets, resepctively.

A bank meeting the three capital ratio tests for the well capitalized category might still be subject to a capital directive requiring it to raise additional capital, based on supervisory assessments of its earnings, asset quality, liquidity, and managerial factors. Any such bank would be classified as adequately capitalized within the prompt corrective action framework.
} 
at least three assets (safe, moderately risky, and excessively risky, respectively), and is therefore outside the scope of the present paper.

We assume that the risk-based standard takes the simple form $\mathrm{C}^{*}=0.06+\mathrm{n}\left(\mathrm{R}-\mathrm{R}_{0}\right)$, where $\mathrm{R}_{0}$ and $\mathrm{n}$ are parameters determining the stringency of the requirement. That is, $C^{*}$ is a linear function of $\mathrm{R}$, the bank's proportionate investment in the risky asset. So long as $\mathrm{R}$ is no greater than $\mathrm{R}_{0}$, required capital equals 0.06. For $R>R_{0}$, required capital exceeds 0.06 by an amount proportional to the gap between $R$ and $R_{0}$. To provide a benchmark for evaluating the impact of risk-basing of the capital standard, we assume that ex-ante, a flat standard $C^{*}=0.06$ is in effect, and that the risk-based standard that is introduced is binding on exante well capitalized banks.

Further, we assume that the risk-based standard does not apply to banks that have become significantly undercapitalized. Rather, regulators would require of such banks a long-run capital target or capital restoration plan that is independent of their current portfolio composition. Formally, at capital levels below some suitably selected threshold level $C_{0}$, the bank becomes subject to the flat capital requirement $C^{\star}=0.06$. This assumption simplifies the analysis because it frees us from having to consider how an endogenous, risk-based capital standard would affect a severely undercapitalized bank's incentive to take on maximal risk. It is also consistent with empirical evidence--in the case of significantly undercapitalized banks, examiners have tended to 
focus on capital in relation to total assets (the leverage ratio) rather than risk-weighted assets (Peek and Rosengren 1995b, c).

In sum, banks are subject to a capital rule that depends on their current capital level $\mathrm{C}$ and (when $\mathrm{C} \geq \mathrm{C}_{0}$ ) on the amount of risk the bank undertakes:

$$
C^{\star}=0.06+n\left(R-R_{0}\right) \text { if } C \geq C_{0} \text {, } C^{*}=0.06 \text { otherwise. }
$$

To model the impact of such a capital rule on bank risk, we substitute (13) for $C^{*}$ in the dynamic optimization problem (6), which is then solved as follows.

Solution procedure. As a first step, we solve a related dynamic optimization problem. Let $\mathrm{k}$ be a given, non-negative integer and define:

$$
C^{k}=0.06+(0.002) k ; \quad R^{k}=R_{0}+\left(C^{k}-0.06\right) / n \text {. }
$$

We consider the dynamic optimization problem (6) subject to the constraints:

$$
C^{*}=C^{k} ; \quad R(C) \leq R^{k} \text { if } C_{0} \leq C \leq C^{k} .
$$

An intuitive interpretation of these constraints is that the bank commits to a self-imposed "capital target" ( $\left.C^{k}\right)$ which governs payment of dividends in the same way that a flat, regulatory standard would. This capital target together with a capital rule of the form (13) implies an upper bound $\left(R^{k}\right)$ on bank risk-taking. ${ }^{26}$ For any given k, computing a numerical solution to this problem is straightforward. Let $R^{\star}(C, k)$ denote this solution.

The next step is to solve (6) subject to (15) for all $\mathrm{k}$ within

\footnotetext{
${ }^{26}$ Note that $R^{k}$ is the proportional investment in the risky asset equating required capital (under the risk-based standard) with the bank's capital target.
} 
a relevant range. The solutions $\mathrm{R}^{*}(\mathrm{C}, \mathrm{k})$ can be examined and compared to identify $R^{*}\left(C, k^{*}\right)$, the solution to the model under the risk-based capital rule (13). Precisely how this is accomplished is best understood by means of an example, to which we now turn our attention .

Numerical computations. Suppose (in regard to the risky asset) that $\mathrm{y}_{0}=1.145, \mathrm{~d}=0.08$, and $\mathrm{b}^{2}=0.33$. In addition, let $\pi_{1}=\pi_{2}=0.0025$, and let $n=1$ and $R_{0}=0.50$ in (13). ${ }^{27}$ First, we derive the solution to (6) under alternative capital targets $\mathrm{C}^{\mathrm{k}}$ as defined by (15) .

A bank can choose 0.06 as its capital target $(k=0)$, in which case it faces the constraint $\mathrm{R} \leq 0.50$ (at capital levels $\mathrm{C}_{0}$ and above), or it can set a target capital level of 0.062 (k=1), enabling it to invest up to 0.55 in the risky asset. Alternatively, the bank can set a target capital level of 0.064 $(\mathrm{k}=2)$ and invest up to 0.60 in the risky asset (or it can choose yet a higher capital target.) The solutions implied by each of these three alternatives are presented in table 6. Alongside each solution we provide the associated return-on-equity (ROE) at each level of capital. ${ }^{28}$

Next, we establish that the configuration corresponding to the capital target of $0.064\left(\mathrm{k}^{*}=2\right)$ represents the actual solution to the model under the specified capital rule (13). In particular, we show that regardless of its ex-ante level of capitalization, the

\footnotetext{
${ }^{27}$ In addition, assume that $C_{0}>0.01$.

${ }^{28}$ Return-on-equity equals $100(1-\delta) \mathrm{V}(\mathrm{C}) / \mathrm{C}$.
} 
bank's equity holders are best off under a commitment to raise bank capital to 0.064 and to maintain 0.064 as a permanent capital target, compared to the other two alternatives depicted in table 6 . Consider a bank that, ex-ante, is well capitalized (at capital level 0.06 ) and is investing 0.55 in the risky asset (in accordance with the solution in column I of table 3a). If ex-post the bank chooses to reduces its investment in the risky asset to 0.50 and maintain its current level of capitalization, then it will earn an average $\mathrm{ROE}$ of 22.481 (a decline of 0.630 relative to its ex-ante ROE of 23.111). If the bank opts to build capital to 0.062 , then it will earn a marginal ROE of $(23.104+22.563) / 2=22.8335$ on its unit of reinvested earnings; since this marginal ROE exceeds 22.481, this strategy dominates the first one. However, if the bank opts to build its capital to 0.064 , then it will earn an even higher marginal ROE: [(23.629+23.091)/2+(23.091+22.629)/2]/2= 23.110. Hence, the latter strategy dominates the other two. Continuing in this manner it is shown that the latter alternative (0.064) is preferred to any that involves a still higher capital target. Thus, commitment to a capital target of 0.064 is the preferred alternative for an ex-ante well capitalized bank, and it must be likewise for an ex-ante undercapitalized bank, since the goal of such a bank is to be well-capitalized. Hence, following the imposition of the capital rule (13), an ex-ante well capitalized bank commits to increase its capital to 0.064 , which also becomes the capital target for any bank (regardless of initial capitalization), so that the solution to the model coincides with 
that under $C^{\star *}=0.064$ in table 6. Note that imposition of the capital rule (13) thus entails increased risk-taking and a higher effective capital standard, compared to the ex-ante, flat capital requirement $C^{\star}=0.06$.

Assessing the impact of a risk-based standard. Solving (6) subject to (13) in this way, for various $n$ and $R_{0}$, an overall pattern emerges. If the capital rule (13) (as applied to banks at capital levels above $\mathrm{C}_{0}$ ) is not too stringent (for example, $\mathrm{n}=1$ and $R_{0} \geq 0.40$, or $n=2$ and $R_{0}=0.50$ ), then it entails increased risk-taking and a higher effective capital requirement, compared to a flat standard $C^{\star}=0.06$. A comparatively stringent rule, however (e.g., $\mathrm{n}=2$ and $\mathrm{R}_{0} \leq 0.45$, or $\mathrm{n}=3$ and $\mathrm{R}_{0} \leq 0.50$ ), entails reduced risk-taking compared to a flat capital standard $C^{\star}=0.06$. Moreover, in the latter case, the reduction in risk-taking will be sufficient to maintain a capital requirement of 0.06 , but it may much larger than is necessary for that purpose. For example, in the case $n=2$ and $R_{0}=0.045$, a bank at capital level 0.06 invests only 0.10 in the risky asset.

The 8 percent risk-based standard adopted in 1988 was a minimum capital standard for banks. The regulations provided and continue to provide substantial leeway for regulators to set more stringent standards for all but the strongest institutions (Peek and Rosengren 1995a). For instance, banks meeting regulatory minimum standards often have been required to increase their capital ratios or to set aside additional reserves for loan losses based on how supervisory staff have assessed the bank's lending 
history, its asset quality, or its managerial strengths and weaknesses (Peek and Rosengren 1995a,b,c). Therefore, de facto standards imposed by regulators vary considerably across individual banks. Our model predicts, then, that the impact of risk-based standards may be ambiguous across banks, and that indeed is the finding of recent empirical studies (see, for instance, Berger and Udell 1994 and Hancock and Wilcox 1994). Moreover, while the model suggests that a risk-based standard can potentially remedy the problem of excessive risk-taking (compared to premia surcharges or higher capital requirement), it also shows that the standard has to be sufficiently stringent for it to be effective.

\section{Concluding Remarks}

This paper sets up a model banking firm, calibrates it using realistic parameter values, and applies it to analyze the impacts on bank risk-taking of increased capital standards, capital-based premia differentials, and risk-based capital requirements. A bank is assumed to operate in a multi-period setting; the bank's capital may fluctuate over time depending on the realized returns on loans, as will the bank's portfolio choices. Thus, we consider the dynamics of bank portfolio choice and the behavior of wellcapitalized as well as undercapitalized banks.

A general implication of the model is that the amount of risk a bank undertakes depends on the bank's current capital position, with the relationship being roughly U-shaped. A severely undercapitalized bank typically takes on maximal risk in an effort 
to improve its capital position, even if the risky asset provides a lower expected return than the safe asset. This result suggests that moral hazard is a serious problem among banks near to insolvency; thus, it provides a formal rationale for the prompt corrective action provisions of FDICIA. As capital rises to a more modestly undercapitalized level, maximal risk-taking typically is replaced by a far more conservative strategy, whereby the bank takes on comparatively little risk. Apparently, a bank's predominant concern at this point is to avoid insolvency or further erosions of capital. Then, as capital rises to the wellcapitalized (regulatory minimum) level, a bank tends to take on more risk, assuming that riskier assets yield a higher expected return. A well-capitalized bank can afford to take more risk because it is more remote from bankruptcy. It is in a position to be able to recover from a substantial erosion of capital due to loan losses.

In the case of a flat (not risk-based) capital requirement, if the capital requirement is increased, then an ex-ante well capitalized bank will take on additional portfolio risk as it adds capital to comply with the new standard. This is consistent with the overall U-shape of the solution, whereby beyond the lowest capital levels, risk-taking tends to increase with capitalization. In most cases, however, an increase in the capital standard is found to have little impact on risk-taking behavior among undercapitalized banks. In one exceptional case, involving a very risky asset having an expected return lower than the return on the 
safe asset, an increased flat capital standard results in expanded risk-taking among significantly undercapitalized banks.

The model has striking implications with respect to the impact of capital-based deposit insurance premia. A primary intent of the Congress in mandating "risk-related" pricing of deposit insurance was to create a disincentive against banks engaging in risky activities. We find, however, that a premium surcharge on undercapitalized banks has a severe impact in the form of a substantial widening of the capital range (among undercapitalized banks) over which maximal risk-taking occurs. Further, ex-post pricing of risk as represented by the premium surcharge has no appreciable impact on the behavior of a well-capitalized bank.

The model suggests that an increased risk-based capital standard is analogous to a higher flat standard, if the risk-based rule is not too stringent. That is, an ex-ante well capitalized bank will respond to the increased standard by raising additional capital and taking on more portfolio risk. If the risk-based rule is sufficiently stringent, however, then raising the standard will have a moderating impact on bank risk-taking. The latter result suggests that risk-based capital requirements are potentially an effective way to curtail moral hazard.

Although significantly undercapitalized banks in our model respond to capital-based insurance premia by increasing the riskiness of their portfolios, it should be noted that the prompt corrective action provisions of FDICIA are intended to promote effective regulatory responses to such behavior. Nevertheless, our 
model suggests that some of the recent regulatory initiatives could have some unintended consequences. 
TABLE 1

Calibrations of the Model

$$
\begin{aligned}
& \mathrm{x}=0.08 \\
& \rho_{0}=0.048 \\
& \mathrm{~F}=0.02 \\
& \delta=0.94
\end{aligned}
$$

TABLE 2

Distributions of Loan Losses: Simulated Risky Assets

A

$$
\begin{gathered}
\mathrm{d}=.08 ; \mathrm{b}^{2}=.33 \\
\mathrm{y}_{0}=1.145
\end{gathered}
$$

B

$$
\begin{gathered}
d=.08 ; \quad b^{2}=.25 ; \\
y_{0}=1.145
\end{gathered}
$$

$\underline{\text { Percentile }}$

$\begin{array}{lll}1 \text { st } & 0.000 & 0.000 \\ 5 \text { th } & 0.000 & 0.000 \\ 25 \text { th } & 0.004 & 0.008 \\ 50 \text { th } & 0.017 & 0.020 \\ 75 \text { th } & 0.056 & 0.058 \\ 95 \text { th } & 0.221 & 0.193 \\ 99 t h & 0.388 & 0.330 \\ 100 t h \text { (maximum) } & 0.693 & 0.602\end{array}$


TABLE $3 a$

Solutions to the Model:

$\underline{C^{*}=0.06 \text { and } \pi_{1}=\pi_{2}=0.0025}$

Calibrations of the Loss Distribution

$\mathrm{d}=.08$
$\mathrm{~b}^{2}=.33$
$\mathrm{Y}_{0}=1.145$
$\mathrm{Rt}=1.089$

$d=.08$

$\mathrm{b}^{2}=.30$

$\mathrm{y}_{0}=1.145$

$\mathrm{Rt}=1.090$

$d=.08$
$b^{2}=.25$
$y_{0}=1.145$
$R t=1.091$

Solutions $R^{*}(C)$
$0<\mathrm{C} \leq 0.006$
$\mathrm{R}^{\star}=1.00$
$\mathrm{R}^{\star}=1.00$
$R^{\star}=0.05$
$0.006<\mathrm{C} \leq 0.008$
$R^{\star}=1.00$
$R^{*}=0.05$
$R^{\star}=0.05$
$0.008<\mathrm{C} \leq 0.028$
$R^{*}=0.05$
$R^{\star}=0.05$
$R^{*}=0.05$
$0.028<\mathrm{C} \leq 0.042$
$R^{*}=0.05$
$R^{*}=0.05$
$\mathrm{R}^{\star}=0.10$
$0.042<\mathrm{C} \leq 0.048$
$R^{\star}=0.10$
$R^{*}=0.10$
$R^{\star}=0.10$
$0.048<\mathrm{C} \leq 0.052$
$R^{*}=0.10$
$R^{*}=0.10$
$R^{\star}=0.15$
$0.052<\mathrm{C} \leq 0.056$
$R^{\star}=0.10$
$R^{\star}=0.55$
$R^{\star}=0.15$
$0.056<C \leq 0.060$
$R *=0.55$
$R *=0.60$
$R^{*}=0.65$ 


\section{TABLE 3b}

Solutions to the Model:

$\underline{C^{\star}}=0.06$ and $\pi_{1}=\pi_{2}=0.0025$

\section{Calibrations of the Loss Distribution}

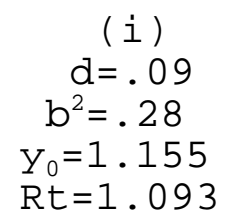

(i)

$b^{2}=.28$

$\mathrm{y}_{0}=1.155$

$\mathrm{Rt}=1.093$

$(i \mathrm{i})$
$\mathrm{d}=.09$
$\mathrm{~b}^{2}=.25$
$\mathrm{Y}_{0}=1.155$
$\mathrm{Rt}=1.093$

(iii)
$\mathrm{d}=.11$
$\mathrm{~b}^{2}=.20$
$\mathrm{y}_{0}=1.168$
$\mathrm{Rt}=1.091$

(iii)

$\mathrm{d}=.11$

$y_{0}=1.168$

$\mathrm{Rt}=1.091$

$$
\begin{gathered}
(i v) \\
\mathrm{d}=.15 \\
\mathrm{~b}^{2}=.30 \\
\mathrm{y}_{0}=1.1825 \\
\mathrm{Rt}=1.077
\end{gathered}
$$

\begin{tabular}{|c|c|c|c|c|}
\hline $0<\mathrm{C} \leq 0.006$ & $R^{\star}=1.00$ & $R^{\star}=1.00$ & $R^{\star}=1.00$ & $R^{\star}=1.00$ \\
\hline $0.006<C \leq 0.008$ & $R^{*}=1.00$ & $R^{*}=0.05$ & $R^{*}=1.00$ & $R^{*}=1.00$ \\
\hline $0.008<\mathrm{C} \leq 0.010$ & $R^{\star}=1.00$ & $R^{\star}=0.05$ & $R^{\star}=0.05$ & $R^{\star}=1.00$ \\
\hline $0.010<\mathrm{C} \leq 0.032$ & $R^{\star}=0.05$ & $R^{*}=0.05$ & $R^{\star}=0.05$ & $R^{\star}=1.00$ \\
\hline $0.032<C \leq 0.036$ & $R^{\star}=0.05$ & $R^{\star}=0.10$ & $R^{\star}=0.05$ & $R^{\star}=1.00$ \\
\hline $0.036<C \leq 0.042$ & $R^{\star}=0.10$ & $R^{\star}=0.10$ & $R^{\star}=0.05$ & $R^{\star}=0.05$ \\
\hline $0.042<\mathrm{C} \leq 0.052$ & $R^{*}=0.10$ & $R^{*}=0.10$ & $R^{*}=0.10$ & $R *=0.05$ \\
\hline $0.052<C \leq 0.056$ & $R^{\star}=0.50$ & $R^{\star}=0.55$ & $R^{\star}=0.10$ & $R^{\star}=0.05$ \\
\hline $0.056<C \leq 0.060$ & $R^{\star}=0.55$ & $R^{\star}=0.60$ & $R^{\star}=0.50$ & $R^{\star}=0.05$ \\
\hline
\end{tabular}

Solutions $R^{\star}(C)$ 
TABLE 4

The Effect of a Higher Capital Requirement:

$$
\underline{C^{*}=0.07 \text { and } \pi_{1}=\pi_{2}=0.0025}
$$

\section{Calibrations of the Loss Distribution}

$$
\begin{gathered}
\mathrm{d}=.08 \\
\mathrm{~b}^{2}=.33 \\
\mathrm{y}_{0}=1.145
\end{gathered}
$$

$$
\begin{gathered}
\mathrm{d}=.11 \\
\mathrm{~b}^{2}=.20 \\
\mathrm{y}_{0}=1.168
\end{gathered}
$$$$
\mathrm{d}=.15
$$

Solutions $R^{*}(C)$

$\begin{array}{llll}0<C \leq 0.008 & R^{\star}=1.00 & R^{\star}=1.00 & R^{\star}=1.00 \\ 0.008<C \leq 0.010 & R^{\star}=0.05 & R^{\star}=0.05 & R^{\star}=1.00 \\ 0.010<C \leq 0.042 & R^{\star}=0.05 & R^{\star}=0.05 & R^{\star}=1.00 \\ 0.042<C \leq 0.044 & R^{\star}=0.05 & R^{\star}=0.10 & R^{\star}=0.05 \\ 0.044<C \leq 0.062 & R^{\star}=0.10 & R^{\star}=0.10 & R^{\star}=0.05 \\ 0.062<C \leq 0.066 & R^{\star}=0.60 & R^{\star}=0.55 & R^{\star}=0.05 \\ 0.066<C \leq 0.068 & R^{\star}=0.65 & R^{\star}=0.55 & R^{\star}=0.05 \\ 0.068<C \leq 0.070 & R^{\star}=0.65 & R^{\star}=0.60 & R^{\star}=0.05\end{array}$


TABLE 5

The Impact of a Deposit Insurance Premium Differential:

$$
\underline{C^{*}=0.06} \text { and } \pi_{1}=0.0025 ; \quad \pi_{1}=0.0035
$$

\section{Calibrations of the Loss Distribution}

$$
\begin{gathered}
\mathrm{d}=.08 \\
\mathrm{~b}^{2}=.33 \\
\mathrm{y}_{0}=1.145
\end{gathered}
$$

$d=.08$

$\mathrm{b}^{2}=.25$

$\mathrm{y}_{0}=1.145$ (iii)

$$
\begin{gathered}
\mathrm{d}=.11 \\
\mathrm{~b}^{2}=.20 \\
\mathrm{y}_{0}=1.168
\end{gathered}
$$

\begin{tabular}{|c|c|c|c|c|}
\hline $0<\mathrm{C} \leq 0.004$ & $R^{\star}=1.00$ & $R^{\star}=1.00$ & $R^{*}=1.00$ & $R^{*}=1.00$ \\
\hline $0.004<C \leq 0.028$ & $R^{\star}=1.00$ & $R^{*}=0.05$ & $R^{\star}=1.00$ & $R^{*}=1.00$ \\
\hline $0.028<C \leq 0.030$ & $R^{\star}=1.00$ & $R^{\star}=0.10$ & $R^{\star}=1.00$ & $R^{*}=1.00$ \\
\hline $0.030<C \leq 0.032$ & $R^{\star}=0.05$ & $R^{\star}=0.10$ & $R^{\star}=1.00$ & $R^{\star}=1.00$ \\
\hline $0.032<C \leq 0.038$ & $R^{\star}=0.05$ & $R^{\star}=0.10$ & $R^{*}=0.05$ & $R^{*}=1.00$ \\
\hline $0.038<C \leq 0.040$ & $R^{\star}=0.05$ & $R^{\star}=0.10$ & $R^{*}=0.10$ & $R^{*}=1.00$ \\
\hline $0.040<C \leq 0.046$ & $R^{\star}=0.10$ & $R^{\star}=0.10$ & $R^{*}=0.10$ & $R^{*}=1.00$ \\
\hline $0.046<C \leq 0.048$ & $R^{\star}=0.10$ & $R^{\star}=0.10$ & $R^{\star}=0.10$ & $R^{*}=0.05$ \\
\hline $0.048<C \leq 0.056$ & $R^{*}=0.10$ & $R^{\star}=0.15$ & $R^{*}=0.10$ & $R^{*}=0.05$ \\
\hline $0.056<C \leq 0.058$ & $R^{*}=0.55$ & $R^{\star}=0.15$ & $R^{*}=0.50$ & $R^{*}=0.05$ \\
\hline $0.058<\mathrm{C} \leq 0.060$ & $R^{\star}=0.55$ & $R^{\star}=0.65$ & $R^{*}=0.50$ & $R^{*}=0.05$ \\
\hline
\end{tabular}

(iv)

$\mathrm{d}=.15$

$\mathrm{b}^{2}=.30$

$\mathrm{y}_{0}=1.1825$

Solutions $R^{*}(C)$ 


\section{TABLE 6}

The Impact of a Risk-Based Capital Standard:

$$
\begin{gathered}
\mathrm{C}^{\star}=0.06+(\mathrm{R}-0.50) ; \pi_{1}=\pi_{2}=0.0025 \\
\underline{\mathrm{d}=0.08 ; \quad \mathrm{b}^{2}=0.33 ; \quad \mathrm{V}_{0}=1.145}
\end{gathered}
$$

$C \star \star=0.060$

Solution (ROE)

$R^{*}=0.10 \quad(25.701)$

$R^{\star}=0.50 \quad(24.963)$

$R^{\star}=0.50 \quad(23.273)$

$R^{\star}=0.50 \quad(23.633)$

$R^{\star}=0.50 \quad(23.037)$

$R^{\star}=0.50 \quad(22.481)$

$\mathrm{C}=0.062$

$\mathrm{C}=0.064$

$$
C \star \star=0.062
$$

Solution (ROE)

$R^{\star}=0.10 \quad(26.389)$

$R^{\star}=0.10 \quad(25.619)$

$R^{\star}=0.10 \quad(24.907)$

$R^{\star}=0.10 \quad(24.245)$

$R^{\star}=0.55 \quad(23.681)$

$R^{\star}=0.55 \quad(23.104)$

$R^{\star}=0.55 \quad(22.563)$

$--------1$
$C \star \star=0.064$

Solution (ROE)

$R^{\star}=0.10 \quad(27.050)$

$R^{\star}=0.10 \quad(26.261)$

$R^{\star}=0.10 \quad(25.527)$

$R^{\star}=0.10 \quad(24.846)$

$R^{\star}=0.55 \quad(24.224)$

$R^{\star}=0.55 \quad(23.629)$

$R^{\star}=0.60 \quad(23.091)$

$R^{\star}=0.60 \quad(22.629)$

${ }^{a}$ At capital levels below 0.05, all three solutions coincide with column (i) of table $3 a$. 


\section{REFERENCES}

Avery, Robert B., and Allen N. Berger, "Risk-Based Capital and Deposit Insurance Reform," Journal of Banking and Finance 15 (1991), pp. 847-874.

Bhattacharya, Sudipto, and Anjan V. Thakor, "Contemporary Banking Theory," Journal of Financial Intermediation 3 (1993), pp. 250 .

Berger, Allen N., Richard J. Herring, and Giorigio P. Szego, "The Role of Capital in Financial Institutions," Journal of Banking and Finance 19 (1995), pp. 393-430.

Berger, Allen N., and Gregory Udell, "Did Risk-Based Capital Allocate Bank Credit and Cause a 'Credit Crunch' in the U.S.?" Journal of Money, Credit and Banking 26 (1994), pp. 585-628.

Berlin, Mitchell, Anthony Saunders, and Gregory F. Udell, "Deposit Insurance Reform: What are the Issues and What Needs to be Fixed?," Journal of Banking and Finance 15 (1991), pp. 735752 .

Carey, Mark, and Wayne Luckner, "Spreads on Privately Placed Bonds 1985-89: A Note," mimeo, Board of Governors of the Federal Reserve System (1994).

Carey, Mark, Stephen Prowse, John Rea, and Gregory Udell, "The Economics of the Private Placement Market," Staff Study no. 166, Board of Governors of the Federal Reserve System (1993).

Furlong, Frederick T., and Michael C. Keeley, "Capital Regulation and Bank Risk-Taking: A Note," Journal of Banking and Finance 13 (1989), pp. 883-891.

Gennotte, Gerard, and David Pyle, "Capital Controls and Bank Risk," Journal of Banking and Finance 15 (1991), pp. 805-824.

Jones, David S., "Risk-Based Capital Requirements Against Asset Backed Securities," mimeo, Board of Governors of the Federal Reserve System (1995).

Hancock, Diana, and James A. Wilcox, "Bank Capital and the Credit Crunch: The Roles of Risk-Weighted and Unweighted Capital Regulations," Journal of the American Real Estate and Urban Economics Association 22 (1994), pp.59-94.

Kahane, Yehuda, "Capital Adequacy and the Regulation of Financial Intermediaries," Journal of Banking and Finance 1 (1977), pp. 207-217. 
Kareken, John H., and Neil Wallace, "Deposit Insurance and Bank Regulation: A Partial Equilibrium Exposition," Journal of Business 51 (1978), pp. 413-438

Keeley, Michael C., "Deposit Insurance, Risk, and Market Power in Banking," American Economic Review 80 (1990), pp. 305-360.

Keeley, Michael C., and Frederick T. Furlong, "A Reexamination of Mean-Variance Analysis of Bank Capital Regulation," Journal of Banking and Finance 14 (1990), pp. 69-84.

Keeton, William R., "Substitutes and Complements in Bank RiskTaking and the Effectiveness of Regulation," draft, Federal Reserve Bank of Kansas City (1988).

Kim, Daesik, and Anthony M. Santomero, "Risk in Banking and Capital Regulation," Journal of Finance 43 (1988), pp. 1219-1233.

Koehn, Michael, and Anthony M. Santomero, "Regulation of Bank Capital and Portfolio Risk," Journal of Finance 35 (1980), pp. $1235-1250$.

McAllister, Patrick H., and John J. Mingo, "Bank Capital Requirements for Securitized Loan Pools," Journal of Banking and Finance (forthcoming).

Moody's Investor Services, "Corporate Bond Defaults and Default Rates: 1970-1994," (January 1995).

Peek, Joe, and Eric S. Rosengren, "Bank Regulation and the Credit Crunch," Journal of Banking and Finance 19 (1995a), pp. 679692 .

Peek, Joe, and Eric S. Rosengren, "Prompt Corrective Action: Can Early Intervention succeed in the Absence of Early Identification," draft, Federal Reserve Bank of Boston (1995b) .

Peek, Joe, and Eric S. Rosengren, "Prompt Corrective Action Legislation: Does it Make a Difference?," draft, Federal Reserve Bank of Boston (1995C).

U.S. Small Business Administration, The State of Small Business: A Report of the President. United States Government Printing Office, Washington (1993).

Wall, Larry D., "Capital Requirements for Banks: A Look at the 1981 and 1988 Standards," Economic Review, Federal Reserve Bank of Atlanta (March/April 1989), pp. 14-29. 


\title{
THE IMPACT OF CAPITAL-BASED REGULATION ON BANK RISK-TAKING: A DYNAMIC MODEL
}

\author{
Paul S. Calem and Rafael Rob
}

\begin{abstract}
In this paper, we model the dynamic portfolio choice problem facing banks, calibrate the model using empirical data from the banking industry for 1984-1993, and assess quantitatively the impact of recent regulatory developments related to bank capital. The model suggests that two aspects of the new regulatory environment may have unintended effects: higher capital requirements may lead to increased portfolio risk, and capitalbased premia do not deter risk-taking by well-capitalized banks and tend to promote risk-taking among undercapitalized banks. On the other hand, risk-based capital standards may have favorable effects provided the requirements are stringent enough.
\end{abstract}

